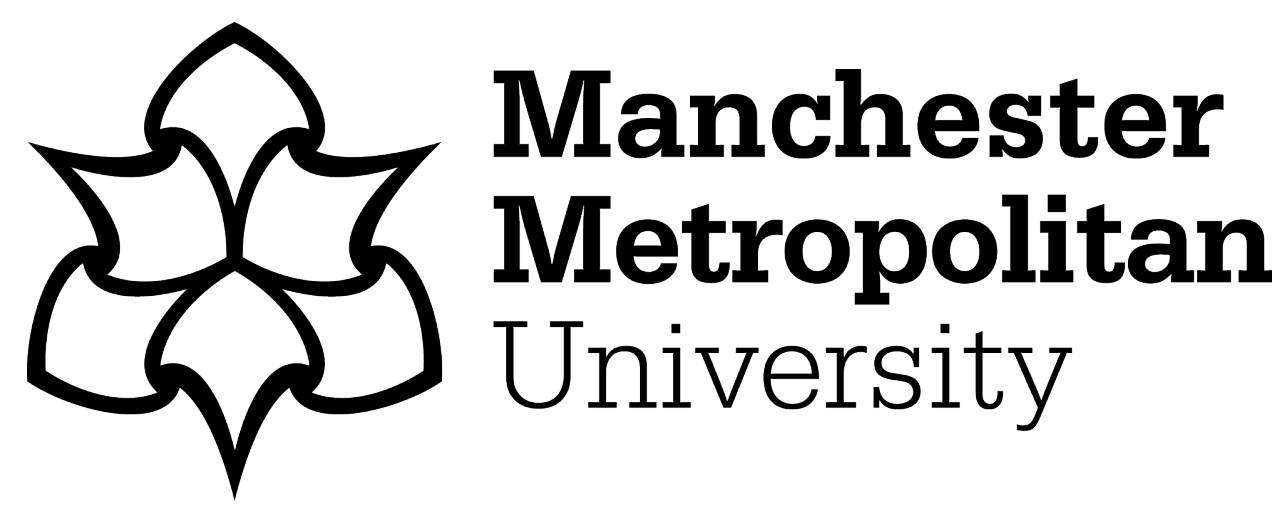

Clifton, J, Hampton, $M$ and Jeyacheya, Julia ORCID logoORCID: https://orcid.org/0000-0003-4245-9453 (2018) Opening the box? Tourism planning and development in Myanmar: Capitalism, communities and change. Asia Pacific Viewpoint, 59 (3). pp. 323-337. ISSN 1360-7456

Downloaded from: https://e-space.mmu.ac.uk/620640/

Version: Accepted Version

Publisher: Wiley

DOI: https://doi.org/10.1111/apv.12200

Please cite the published version 


\title{
Opening the box? Tourism planning and development in Myanmar: capitalism, communities and change
}

\author{
Julian Clifton (University of Western Australia), ${ }^{1}$ Mark P. Hampton (University of Kent) \\ and Julia Jeyacheya (Manchester Metropolitan University)
}

1. Contact Author email: Julian.clifton@uwa.edu.au

\begin{abstract}
Myanmar (formerly Burma) is emerging from almost six decades of international isolation into a period of rapid economic growth. Following moves towards increasing democratisation since 2011, Myanmar's tourism industry has been propelled from "tourism pariah" to rising "tourism star" and is experiencing an extraordinary growth in tourism arrivals with associated revenues and investment. The unique rapidity of Myanmar's recent transition enables an examination of how contemporary forces of globalisation and neoliberalism determine the direction and mode of tourism development from its beginnings. We show how tourism is perceived by the national government as an engine for rural development, conservation and livelihood creation for poor and rural communities. We then demonstrate how this is re-shaped by a globalised tourism industry into a socially and economically exclusive model which capitalises upon weak governance and disempowered local stakeholders. We conclude with observations which may point towards a more sustainable and responsible tourism industry.
\end{abstract}

Keywords: tourism planning; development policy; neoliberalism; economic development; Southeast Asia 


\section{Introduction}

For many countries in the Asia-Pacific region, international tourism has long been encouraged as a development tool by organisations including the World Bank, Asian Development Bank, OECD and other development agencies (Scheyvens, 2011a, b). More recently, some countries in the region such as China and South Korea increasingly represent significant source markets in the international tourism sector. As a result, international tourism has proved to be highly attractive for employment, income-generation, and contributing to GDP and government revenues, and has been promoted as a key policy agenda of international financial institutions, private sector organisations, non-governmental organisations and national governments (Fletcher, 2011; Lee et al. 2015).

The rise of mass tourism in the 1960s with its Fordist mode of production, was followed from the 1970s onwards by increasing demand for "alternative" tourism offering a variety of flexible, individually-tailored trips concurrent with capitalism's shift towards a disorganised, post-Fordist form centred on flexible accumulation (Harvey 1989) through diverse structures. This led to the development of a myriad niche or boutique markets designed to offer an outlet for every tourist's particular taste, including such diverse (and disturbing) products as war, sex and slum tourism (Gibson 2009; Holden, 2013). The expansion of the ability to travel for leisure has also been accompanied by the development of more specialised products centred on ethical, responsible or green travel (Hampton, 2013; Fennell, 2015).

Tourism and its more specialised sectors such as ecotourism have been promoted as a means of achieving economic growth that is environmentally sustainable or beneficial, as reflected in three of the seventeen Sustainable Development Goals (UNWTO, 2015). Viewed through a more critical neoliberal lens, however, tourism and ecotourism in particular can be understood as reflecting the needs of global capitalism through creating new markets from the commodification of natural resources and the experiences associated with them. As Duffy 
(2015: 539) argues: 'Tourism, including the subset of nature-based tourism, produces contradictions because it relies on creating attractions from the very environments it is simultaneously using, changing and reshaping'. In essence, by generating capital based on in situ consumption of natural resources, such as through visits to protected areas, ecotourism may be viewed as an exemplary means by which capitalism seeks to provide for ecologically sustainable economic growth. In this, sense, "sustainable" tourism may be seen as providing an 'environmental fix' (Castree 2008: 146) similar to the various spatial-temporal fixes that tourism in general provides to capitalism (Harvey, 1989).

Yet this is still not the entire story, for in addition to helping to forestall an ecological crisis, ecotourism may capitalise upon this same crisis narrative (Igoe et al. 2010). Klein (2007) contends that neoliberal capitalism in general displays a remarkable ability to turn crises to which it has contributed into opportunities for economic growth. Brockington and colleagues (2008) build upon this analysis to suggest that somewhat ironically international conservation in general may actually gain value from the disappearance of the biodiversity it seeks to preserve, as that which remains grows increasingly desirable. Neves (2010) identifies this dynamic in cetacean tourism (whale watching), whereby the activity's value has increased in concert with its objects' depletion.

Mowforth and Munt (2016) note that capitalism - through new tourism activities such as ecotourism - is able to transform crises to which it has contributed into marketable commodities. Many ecotourism sites, in fact, explicitly market themselves as desirable destinations based on the probability that they will cease to exist at a later stage. In this respect, ecotourism may function as a form of what Büscher (2010: 263) calls 'derivative nature', in that resources are valued not in and of themselves but rather in terms of their projected worth relative to a hypothetical future scenario of degradation and loss. 
Therefore, tourist demand and capitalist profits are mutually enhanced in cases where the environmental "attraction" is scarce or threatened and marketed as an object to be witnessed by tourists before it disappears or becomes extinct. Tourism can thus be seen as an agent of neoliberal capitalism through firstly, ensuring that profits can continue to be derived from a declining resource base (and arguably closely linked to fundamental crisis implicit in capitalism - see Gibson 2009) and secondly, in the dominance of non-state actors such as NGOs and the private sector in capturing, owning and selling these values with the concomitant diminution in the role and importance of the state (Fletcher, 2011; Fletcher and Neves, 2012; Carroll and Jarvis, 2015).

In this paper we examine the influence of international tourism as an agent of neoliberal capitalism. The case of Myanmar is explored: a country experiencing rapid change and an unprecedented transition to what Jones (2014: 145) calls 'state-mediated capitalism' with associated inflows of foreign capital, particularly into its nascent tourism industry as exemplified by significant flows of foreign direct investment (FDI). International tourism in Myanmar is interrogated in this conceptual paper by exploring three related issues. The paper begins by considering how agents of globalised tourism are shaping the overall development of tourism activity within the country. Following this, the paper examines how these impacts are likely to be influenced by government policies relating to responsible tourism and ecotourism. Finally, we discuss the extent to which domestic civil society organisations are capable of mitigating the likely socio-economic consequences of increased globalisation via tourism. 


\section{Evolution of the tourism sector in Myanmar}

\section{Tourism stagnation and revitalisation}

The fortunes of the tourist sector in Myanmar are closely intertwined with internal politics and Myanmar's relationship with other countries. These will be summarised here but see Parnwell (2002), Henderson (2003), Zhou (2005), Barnett (2008) and Valentin and Schilcher (2017) for more detailed discussions of the interplay between politics and tourism in Myanmar. Following independence from Britain in 1948, Myanmar (then known as Burma) experienced a short period of democratic rule which ended in 1962 with General Ne Win's coup d'état. Ne Win's socialist government, termed the Revolutionary Council, followed a policy of economic and political isolation from the outside world for the ensuing three decades. The State Law and Order Restoration Council (SLORC) overthrew Ne Win in 1988 and took power in the violent incident known as 8-8-88. Despite extensive criticism of its human rights record and widespread western economic sanctions, the military regime under General Than Shwe initiated moves to develop tourism in the 1990s, including the facilitation of foreign direct investment (FDI) flows and increased publicity such as the designation of 1996 as "Visit Myanmar $^{1}$ Year" which followed other neighbouring ASEAN countries' successful campaigns. However, in Myanmar's case, it proved far less successful than the SLORC regime hoped for with far fewer international tourists than the perhaps unrealistic target of one million arrivals, and in fact attracted negative publicity and a lengthy boycott (Henderson, 2003; Hudson, 2016; Valentin and Schilcher, 2017). During the 8-8-88 crackdown, Daw Aung San Suu Kyi emerged as the opposition leader and the head of the newly formed National League for Democracy (NLD). In the following years Suu Kyi was continuously put under house arrest, including in 2002 as part of a renewed crackdown on political opponents. This reinforced the longstanding boycott on tourism instigated by Suu Kyi herself in 1995, which was supported by many western tourism operators and NGOs. This boycott campaign was arguably 
successful, as only very few international tourists visited the country during this time. The 2007 'Saffron Revolution' and the effects of Cyclone Nargis in 2008, as well as the consequences of the global financial crisis served to further hamper tourism growth, despite attempts by the government to promote tourism including the easing of visa restrictions and investment to expand Yangon's international airport.

Daw Aung San Suu Kyi was finally released from house arrest after the 2010 elections, resulting in her opposition party's revocation of its support for a full tourism boycott in 2011 and the gradual easing of international economic sanctions over the ensuing months. Furthermore, the enactment of the Foreign Investment Law in 2012 served to stimulate overseas investment in certain sectors including tourism through a range of tax and other incentives.

Figure 1 demonstrates the recent dramatic increase in international arrivals, increasing fivefold from around 800,000 in 2010 to 4.7 million in 2015 at rates exceeding the high level scenarios projected under the Tourism Master Plan of 2013. However, it must be borne in mind that the majority of current international arrivals involve land border crossings, which represented $72 \%$ of all international arrivals in 2015 (Table 1). This reflects the opening of four strategic border crossings with Thailand in 2013 which greatly facilitated travel and trade from nearby centres including Bangkok. Nevertheless, the majority of these arrivals stay less than 24 hours (MoHT, 2013b) and therefore would not qualify as tourists under the United Nations World Tourism Organisation (UNWTO) definition. ${ }^{2}$ Yangon remains the principal port of entry for international air arrivals, with numbers increasing from 297,000 in 2010 to 1.18 million in 2015 (Table 1).

[Figure 1, Table 1] 


\section{Tourism institutions and policies}

Following the election success of the NLD in 2015, a number of rapid changes in government structures and policies in Myanmar have been implemented including merging several ministries in the capital, Nay Pyi Taw, as part of reforms to increase government efficiency (Lwin and Thant, 2016) although it is unclear how effective this may prove to be given the ongoing influence of the military and assorted cronies in the political economy (Ford et al., 2016; Valentin and Schilcher, 2017). It should therefore be noted that the following summary of the tourism sector refers to circumstances at the time of writing (September 2017).

The Ministry of Hotels and Tourism (MoHT) is the lead government agency responsible for tourism-related activities. It is comprised of the Directorate of Hotels and Tourism, which undertakes policy making, tourism planning and regulation, and Myanmar Hotels and Services which handles travel and tour operations and accommodation services. MoHT accommodation regulations differ significantly from neighbouring countries and set arbitrary distinctions between accommodation types which serves to specifically prohibit homestays (Bowman, 2016). Hotels in Myanmar are required to have a minimum of 20 rooms/40 beds and a restaurant. Guest houses must have 10 rooms/20 beds, and bed and breakfasts 4 to 8 rooms (but these must be separate from the owner's house meaning that homestays are not permitted). This strict (and arguably heavy-handed regulation) adds costs and further bureaucracy to local business start-ups. It also prevents entrepreneurs with limited capital starting with 2 or 3 rooms and re-investing to grow their business as happens elsewhere in ASEAN allowing poorer communities to benefit from tourism (Hampton, 2013).

Another 25 government ministries have had advisory and liaison roles in tourismrelated matters (MoHT, 2013a). The Myanmar Tourism Federation was created in 2011, consisting of 11 sub-associations, and takes a lead in activities including tour guide training, establishing an accommodation rating system reflecting ASEAN standards and developing 
tourist information centres. More recently, the Myanmar Responsible Tourism Institute has also been launched funded by international development donors including Swisscontact (MRTI, 2017).

The principal document guiding the long term development of the tourism sector is the Responsible Tourism Policy (MoHT, 2012b). This policy evolved through public and private stakeholder consultation and identifies nine guiding principles and 58 associated action points. These nine principles informed the identification of strategic programs and objectives for tourism as elucidated in the Tourism Master Plan for 2013-2020 (MoHT, 2013a). The details and relationships between these two key documents are illustrated in Figure 2.

[Figure 2]

\section{Methods}

As noted earlier, this paper is broadly a "think piece" that interrogates Myanmar's recent rapid expansion of tourism in the context of neoliberalism and globalisation. The paper is constructed and primarily based upon secondary data collated from the academic literature and official planning materials but is also augmented by selected primary data generated from four separate visits to Myanmar by the authors between 2014 and 2017. Two of these visits were primarily to conduct training workshops with the tourism industry, local communities and developing research collaboration with major universities. On each visit, a number of informal interviews with key stakeholders took place.

Two authors carried out a specific scoping study with fieldwork in November 2014 at Ngapali Beach in Rakhine State, one of Myanmar's three main coastal tourism destinations. The approach was qualitative, with a period of intensive fieldwork applying techniques from rapid rural appraisal including interviews and participant observation (see Chambers, 1983 and 
Ellis and Sheridan, 2014). A series of $n=18$ semi-structured, in-depth interviews were carried out with local businesses ( $\mathrm{n}=13$ ) including owners of hotels and guest houses, restaurants and souvenir shops, employees, and NGO staff as we were keen to hear local "voices". Expatriate managers of hotels and restaurants provided a smaller 'international voice' $(n=5)$. Interview respondents were purposively sampled initially from key stakeholders identified in the resort, with some "snowballing" (chain referral) to lead to further interviews. Discussions were also held in Yangon and Nay Pyi Taw with local and international NGOs and government officials. A follow up observational study in Ngapali was undertaken in May 2016 by one author which added further information. Additional informal discussions with domestic and international NGOs operating in Myanmar, academics and government officials in Yangon, Mandalay, Myeik and Kawthaung were also held during further visits in January and May 2017 by the other authors.

The 18 interviews in Ngapali Beach had an average duration of 65 minutes and were mostly undertaken in English, but local translation assistance was given for three interviews in the Burmese language. Most interviews were carried out at the respondent's place of work but some were undertaken in local tea shops to give respondents a measure of privacy so that they could speak freely. Interviews were not digitally recorded as given the context of Myanmar respondents did not wish to be recorded, however, detailed notes were kept during the interviews in field notebooks and then typed up on laptops. A de-brief meeting with both researchers was held each evening to go over the day's interviews and cross-check the completed interview material. This was designed to allow the team to be reflective about the day's interviews, as reflexivity in the field is being increasingly recognised as an important part of fieldwork research (see Cohen, 2013; and Cupples and Kindon, 2014 for instance). Interview data was then manually coded by theme. The key themes were originally outlined in the pre-fieldwork phase when the interview questions were being drawn up alongside interview 
protocols, but were then augmented in light of emerging new themes from respondents' comments during the semi-structured interviews themselves. The interview data was then analysed on the return from fieldwork.

\section{Analysis}

\section{Tourism and Neoliberalism in Myanmar}

Whilst there remains considerable doubt over the accuracy of official tourist arrivals data (Thu and Kean, 2015), it is evident that the country has experienced an unprecedented increase in international tourist arrivals. China, Thailand, Singapore and South Korea are currently key regional markets in Asia, with the USA, France and Germany representing important western markets (MoHT 2015). This has resulted in rapid increases in direct employment related to tourism in sectors such as hotels, restaurants, tourist transportation and souvenir retail together with growth in indirect tourism-related employment throughout the supply chain. Recent data from the World Travel and Tourism Council (WTTC 2016) estimates that tourism in Myanmar employed around $2.3 \%$ of the labour force directly in 2015 (equivalent to around 660,000 jobs) and directly contributed 2.6 of GDP, rising to a total of $5.9 \%$ of GDP with indirect contributions.

This growth is underpinned by foreign direct investment (FDI) which, following earlier authors (Sanford and Dong 2000; Zhang and Jensen 2007), we are using as a proxy representing the penetration of capitalism via tourism into the new market of Myanmar. Over the longer term period for which data are available (2004 to 2016), a total FDI of US\$56 billion was recorded by official sources (DICA 2016). Electric power and oil and gas have been the principal sectors of investment, accounting for approximately US\$20 billion each, with manufacturing and mining also being significant areas of investment. 
There is, however, a distinct difference in FDI prior and following the 2011 election. From 2004 to 2011, China accounted for $40 \%$ of all FDI, followed by Thailand (25\%) and Hong Kong (18\%), with activity focused on the power generation and oil and gas sectors. Between 2011 and 2016, the number of investing countries increased from 14 to 33, and the proportion of total investment from China and Hong Kong fell to $18 \%$ and $4.5 \%$ respectively. Singapore also became established as the leading source of investment, accounting for $49 \%$ of total FDI between 2011 and 2016, with new sources of investment including the UK and Netherlands representing $6 \%$ and $3 \%$ of total FDI in this period respectively (DICA 2016). Furthermore, a marked shift in the pattern of investment became apparent, with a dramatic decline in power sector investment from 57\% of total FDI prior to 2011 to less than 5\% after 2011 (Figure 3). A growth in sectoral investment was most marked in manufacturing, which increased its proportion of total FDI from $0.5 \%$ prior to 2011 to $26 \%$ after 2011 along with the real estate and tourism sectors, which grew tenfold to represent around $11 \%$ and $8 \%$ of total FDI in the period 2011-2016 respectively. Official tourism statistics indicate that in 2012, there were 12 hotels and associated complexes being built with Singaporean FDI valued at US\$598 million which had increased to 21 hotels and complexes representing FDI of US $\$ 1.5$ billion by 2015 (MoHT 2012a; 2015).

\section{[Figure 3]}

This changing investment pattern reveals that Myanmar is being increasingly integrated into regional circuits of financial capital and the broader neoliberal global economy as FDI flows from a greater number of countries into a more diverse range of activities. It should also be noted that Singapore's primacy as a source of FDI into Myanmar in turn reflects its own position as a global financial hub benefiting from the presence of subsidiary companies from 
OECD countries, underlining the complexity of linkages embedding Myanmar into the global economy (Cook and Nair 2015).

Whilst tourism remains a relatively recent focus of FDI, longer term evidence from other sectors indicates that some projects funded through FDI are associated with wide-ranging concerns including land grabs, forced labour, environmental degradation and ongoing issues with cronies (OECD, 2014; Ford et al. 2016; Shen, 2017). Some of these concerns were echoed through interviewees' comments in Ngapali beach (2014 and 2016) (see Table 2) and these exemplify the dichotomy between the local people's experience of tourism development thus far and in the future, and that of the predominantly European expatriate community. The local residents have a growing awareness of their own poverty and situation as land is sold and tourism develops along their beach. The international respondents also cited concerns based on their experience and knowledge with reference to the business models from neighbouring country destinations, such as Thailand, being adopted in Ngapali.

\section{[Table 2]}

This perception amongst respondents that the central government was pursuing a policy of tourism in Ngapali following the 'Bali model' in reference to external ownership and control of tourism projects was strong. These issues are reflected in a recent review of the tourism sector which highlighted the lack of communication between businesses and local stakeholders combined with the complexity of land policy resulted in worsening socio-economic impacts from increasing tourism development (MCRB 2015).

The preceding discussion has demonstrated that the rapid increase in foreign-led tourism investment associated with the opening up of Myanmar's economy, coupled with a cumbersome bureaucracy and inevitable elements of cronyism, will be manifest in an 
increasingly diverse range of pressures and threats to existing livelihoods. These will now be examined with reference to the extent to which government policies and domestic civil society organisations may counter these potential adverse impacts.

\section{Responsible tourism and ecotourism in Myanmar}

Tourism is seen by the national government as a means to achieve poverty reduction through increasing business opportunities in both urban and rural areas and is highlighted as such in the Framework for Economic and Social Reform (MNPED 2013). Ecotourism has long been promoted as a means by which visitors can contribute towards environmental conservation whilst simultaneously providing additional income-generating opportunities for local communities, thereby fulfilling generic goals relating to sustainable development (Fennell, 2015). The opening of new markets for private sector activity is a hallmark of the neoliberal agenda, necessitating an analysis of how ecotourism is being used as a means to promote and expand this ideal.

Myanmar's Ecotourism Policy outlines a process of planned ecotourism development around 22 designated 'ecotourism sites' representing existing protected areas of varying designations (MOECAF and MoHT 2015). These protected areas underpin Myanmar's commitments to achieve the Aichi Targets relating to protected area coverage under the Convention for Biological Diversity. However, the Policy acknowledges that management is beset by numerous obstacles including lack of financial support, poorly trained and inadequate staffing, weak transport infrastructure and limited baseline environmental data. Ecotourism is envisaged as a means to partially address these problems through generating revenue for protected areas through visitor fees whilst also providing direct and indirect income-generating opportunities for local residents, who number approximately 6.5 million people in and around the protected areas designated as ecotourism sites (MOECAF and MoHT 2015). These 
opportunities range from the development of alternative livelihoods, conservation awareness programs and engagement in supply chain activities including accommodation, food and drink, transport and local handicraft manufacture. However, the Ecotourism Policy implicitly prioritises the development of alternative livelihoods, stating that 'these initiatives are specifically designed to reduce resource dependency upon the protected areas' (MOECAF and MoHT 2015: 22) rather than achieve broader poverty reduction objectives. It is therefore apparent that livelihood diversification within communities in and around these ecotourism sites is perceived as central to improving protected area management and, by consequence, assisting the central government in fulfilling its international biodiversity conservation obligations.

However, the acute and endemic poverty in rural Myanmar reflects decades of government policy relating to agriculture (Rammohan and Pritchard 2014), systematic underinvestment in all aspects of rural social and physical infrastructure (Findlay et al. 2016; Saw et al. 2013) and the effects of continued political instability in conflict areas. The legacy of an autocratic dictatorship is manifest in weak economic governance characterised by corruption, cronyism and excessive bureaucracy which are seen as 'serious obstacles to economic development' (Asian Development Bank 2015: 3). Furthermore, the assumption that local communities would be willing and able to become involved in ecotourism-related activities neglects a host of issues involving the structure and processes of participation which determine the outcomes of any such initiative (Scheyvens 2011b).

There are, therefore, numerous obstacles which will hinder the extent to which local communities and individuals can capitalise upon any opportunities to realise the social and economic benefits of ecotourism as envisaged in the Ecotourism Policy. The development of ecotourism-related alternative livelihoods and involvement in the tourism supply chain within local communities is highly likely to be restricted to low profit activities such as informal 
transport or basic food and drink provision. Fees paid by visitors to protected areas are collected by the central government via the MoHT and thus represent a direct leakage of economic benefits. Furthermore, experience in many other developing countries has shown that, as visitor numbers increase and a destination begins to move through the tourism life cycle (Butler 1980), the extent of local participation may actually decline as integrated tourism enterprises, often based in overseas countries, invest in tourism infrastructure and control its development (Holden, 2013; Hampton and Jeyacheya, 2015).

This situation can be exemplified with reference to Lampi Marine National Park which was gazetted in 1996 and encompasses $205 \mathrm{~km}^{2}$ of the Myeik Archipelago in Tanintharyi Region to the south of the country. Lampi is the only marine protected area in Myanmar and is on the shortlist of ten ecotourism sites identified in the Ecotourism Policy, reflecting its unspoilt nature and rich marine and terrestrial biodiversity. With very little tourist infrastructure in this remote location, visitor activities revolve around live-aboard boat operations focusing largely on snorkelling and diving, many of which are operated from Phuket and elsewhere in Thailand and are geared towards high income visitors with charges ranging up to $\$ 5000$ per person for a five night excursion (C9 Hotelworks 2016). The current Lampi Ecotourism Management Plan identifies illegal fishing, logging and hunting as the principal threats and cites the resident Moken population, pejoratively known as 'sea gypsies' on account of their formerly nomadic lifestyles, as being involved in these activities, whilst also being prone to alcohol and drug abuse on account of the lack of development opportunities (Oikos 2015). Approximately $75 \%$ of the park has been zoned as a no-fishing area, with the remainder being subject to as yet unspecified restrictions on fishing, all of which will clearly impinge upon the capacity of the Moken to maintain their traditional maritime livelihoods. ${ }^{3}$

Given the clear social, economic and political limitations on opportunities for the Moken and other park residents to diversify livelihoods or participate in current marine 
ecotourism activities, it is difficult to see how the goals of the Ecotourism Policy will be met in this context. This is reinforced by approved plans for future ecotourism development focusing upon eco-lodges and other enclave-type resorts (Oikos 2015; C9 Hotelworks 2016) which offer very little scope for local community involvement. It must also be borne in mind that the Myanmar Constitution of 2008 allows for private property rights but asserts the State as the ultimate owner of all land and inshore waters. Local communities are therefore particularly vulnerable to losing access rights or having resources expropriated by the state for the purposes of commercial development such as tourism (MCRB 2015). This process is already being manifest through numerous applications for hotel development on state lands in the Myeik Archipelago amounting to 'thousands of acres' (Eleven Myanmar 2015).

Ecotourism is therefore primarily seen as a vehicle to address shortcomings in protected area management and encouraging further investment in exclusive and enclave-type protected area ecotourism, with little consideration of whether the supposed social and economic benefits of ecotourism will filter down to local resident communities. Indeed, the evidence available to date indicates that the most likely impact of private sector-led ecotourism on these communities will be to enmesh local participants in increasingly precarious livelihoods vulnerable to the globalised drivers of tourism which will in turn diminish their capacity for self-sufficient or sustainable development.

\section{Civil society and tourism development in Myanmar}

The prioritisation afforded to the creation of enabling conditions conducive for private sector investment in ecotourism has many hallmarks of the "deep marketisation" phase of neoliberal development, whereby the state is reduced to a regulator providing the necessary resources for (often overseas) private capital investors and subsequent flows of FDI (Carroll and Jarvis 2015). The question therefore arises as to whether rural communities located at the foci of 
potential future developments have the resilience or capacity to adapt to these changes or mitigate their impacts. In this context, it is worth noting that Myanmar is renowned for its proliferation of village-based civil society institutions, with hundreds of thousands of rural community-based organisations in spheres encompassing health, education and social welfare operating in the void created by the absence of the central state (Prasse-Freeman 2012). This was brought into focus in the aftermath of Cyclone Nargis in 2008, during which existing and newly-formed community-based organisations took a lead role in initiating, coordinating and delivering post-disaster response activities in response to official delays and inefficiencies (Human Rights Watch 2010; Centre for Peace and Conflict Studies 2008).

The empowerment of civil society arising from the networks of trust and communication established in the aftermath of Cyclone Nargis could be grounds for suggesting that community-based organisations would be more willing and able to represent local communities and their opinions relating to the impacts of proposed ecotourism developments than would otherwise be the case. As stated by one such organisation interviewed in 2016: 'Tourism [as a means to stimulate community discussion] is a good way to increase social capital.'

However, the willingness of the authorities to tolerate dissent in matters relating to government policy remains uncertain, whilst there is no defined legal role for civil society in decision-making and corruption remains an endemic problem limiting the capacity for civil society to operate effectively (Asian Development Bank 2015). Furthermore, the more powerful domestic NGOs in Myanmar are commonly staffed by networks of wealthy families and business people who enjoy influential advocacy roles within government (Prasse-Freeman 2012). Prasse-Freeman (2012) further suggests that this may have evolved to the point where the larger domestic NGOs are indistinguishable from state institutions, with whom they share an authoritarian, hierarchical structure and corporatist attitude increasingly divorced from local 
reality. These NGOs are clearly better positioned than rural 'grassroots' community-based organisations to work within the complex global aid community (Bächtold 2015), thereby ensuring that the conservation objectives of international NGOs are less likely to encounter resistance from local civil society.

The very real threats of land confiscation, forced labour and other human rights abuses faced by rural communities in association with "development" projects in Myanmar could be mitigated to some extent by the involvement of the Asian Development Bank, which emphasises good governance and observance of human rights in its contributions to national tourism policy (MoHT 2013a). However, as demonstrated earlier, the reality of tourism development is increasingly driven by FDI from private sector interests in neighbouring countries which often display notably poorer standards in these areas (Simpson and Park 2013). This concern is reinforced by legislation introduced in 2016 which simultaneously enabled full foreign ownership of ecotourism activities and removed the need for approval of ecotourism proposals which was held by the Ministry of Natural Resources and Environmental Conservation [MoNREC, formerly known as the Ministry of Environmental Conservation and Forestry] (Conventus Law 2016). Consequently, the extent to which future ecotourism projects will adhere to responsible tourism policy guidelines espoused by actors such as the ADB, the World Bank, the European Union and others remains in doubt.

\section{Conclusion}

Myanmar is experiencing significant and rapid change resulting from the political reform process and increasing democratisation under the current NLD administration. This paper has examined some of the assumptions of tourism's broader benefits in the context of how tourism is situated within a neoliberalised global economy. Whilst tourism can bring undoubted social, economic and environmental benefits, the prospects of these being realised in Myanmar under 
the current circumstances must be in doubt. We would draw particular attention to the dearth of evidence supporting the implementation of "responsible tourism" and "ecotourism" policies, coupled with the strength of the global pressures for tourism development and the economic vulnerability of communities in tourism destination areas. Notably, it also remains somewhat unclear where the NLD government elected in 2015 stands on these issues. In addition, current political instability and actual conflict in several regions of Myanmar, the challenge of the continuing Rohingya issue, as well as the continuing vested interests of the military and the associated cronies, all reiterate the complexity of Myanmar's political economy and overshadow the profile of tourism development in the country (McPherson, 2017b; Valentin and Schilcher, 2017).

Furthermore, a note of caution should also be sounded when using economic indicators such as foreign direct investment. In contrast to the FDI trends described earlier, recently published data for 2016-17 point to a 30\% reduction in annual FDI (Financial Times 2017). This is attributed to a backlog of FDI approvals coupled with a lack of clarity on national economic policy priorities under the current administration (McPherson 2017a). Such a reduction in FDI, if sustained, would add further weight to the argument that support should be directed towards developing domestic (or regional) tourism initiatives, particularly through diversifying the range of accommodation options across the country, especially outside the current tourism hotspots of Yangon, Mandalay, Bagan and Inle Lake.

One specific, simple legislative change could be made by the tourism ministry which would be to allow the legalisation of homestay accommodation. It is unclear why MoHT appears unwilling to make this modest change. Many of our respondents, NGOs and other stakeholders repeatedly mentioned the urgent need for this change, as despite the widely acknowledged economic benefits of homestays, it remains effectively illegal to host foreigners in homestays in Myanmar (Globserver 2014). As noted earlier, bed and breakfast style 
accommodation for international visitors is permitted but the lengthy and costly approval process constrains many households from providing such services, a situation which could be swiftly remedied through a decentralised and reformed licensing system.

Given the significance of growing regional and international markets contributing to tourism expansion in Myanmar, it remains imperative that government policies are critically and independently reviewed, that robust and evidence-based policy is formulated (and implemented), and crucially, that institutions and tourism ministries are staffed with welltrained senior staff and competent ministers. This, it is suggested, together with civil society organisations being empowered to facilitate appropriate tourism development, will begin to deliver durable and sustainable benefits for both the host communities and for Myanmar's diverse and fragile environments.

\section{Acknowledgements.}

The authors thank all our interview respondents who generously gave up their time, as well as all those who helped guide our thoughts in many informal discussions during our different visits. The Ngapali Beach project was funded by the University of Kent's Faculty of Social Science Research Fund. The usual disclaimers apply. 


\section{References}

Asian Development Bank (2015) Civil society briefs: Myanmar. Retrieved 31 August 2017 from website: http://www.adb.org

Bächtold, S. (2015) The rise of an anti-politics machinery: peace, civil society and the focus on results in Myanmar. Third World Quarterly 36(10): 1968-1983

Barnett, T. (2008) Influencing tourism at the grassroots: the role of NGO Tourism Concern. Third World Quarterly 29: 995-1002.

Bowman, V. (2016) Hotel policy is broken: Here's how to fix it. Frontier Myanmar. Online. 31 October. Retrieved 24 August 2017 from website: https://frontiermyanmar.net/en/hotelpolicy-is-broken-heres-how-to-fix-it

Brockington, D. Duffy, R. and J. Igoe (2008). Nature unbound: Conservation, capitalism and the future of protected areas. London: Routledge.

Büscher, B. (2010) Derivative nature: interrogating the value of conservation in 'Boundless Southern Africa'. Third World Quarterly 31(2): 259-276.

Butler, R.W. (1980) The concept of a tourist area cycle of evolution: implications for management of resources. Canadian Geographer 24(1): 5-12.

C9 Hotelworks (2016) Myanmar’s Mergui archipelago: Tourism market review. Retrieved 31 August 2017 from website: http://www.c9hotelworks.com/

Carroll, T., and D.S.L Jarvis (2015) The new politics of development: citizens, civil society and the evolution of neoliberal development policy. Globalizations 12(3): 281-304.

Castree, N. (2008) Neoliberalising nature: the logics of deregulation and reregulation. Environment and Planning A, 40: 131-152

Centre for Peace and Conflict Studies (2008) Listening to voices from inside: Myanmar civil society's response to Cyclone Nargis. Retrieved 31 August 2017 from website: http://www.centrepeaceconflictstudies.org 
Chambers, R. (1983) Rural development. Putting the last first. London: Longman.

Conventus Law (2016) New Myanmar foreign investment law notification on the prohibited and restricted activities. Retrieved 31 August 2017 from website: http://www.conventuslaw.com/report/new-myanmar-foreign-investment-law-notification-on/ Cook, M. and V.P. Nair (2015) Diversity and development: foreign direct investment in Southeast Asia. Institute of Southeast Asian Studies Perspective 49. Retrieved 31 August 2017 from website: https://www.iseas.edu.sg/images/pdf/ISEAS_Perspective_2015 49.pdf Cupples, J. and Kindon, S. (2014) Returning to University and Writing the Field. In Scheyvens, R. (ed) Development fieldwork: A practical guide. (Second edition) Sage: London.

DICA [Directorate of Investment and Company Administration] (2016) Foreign Direct Investment update. Retrieved 31 August 2017 from website: http://www.dica.gov.mm/en/topic/foreign-investment-country

Duffy, R. (2015) Nature-based tourism and neoliberalism: concealing contradictions. Tourism Geographies, 17 (4): 529-543.

Eleven Myanmar (2015) Two islands in Taninthayi Region rented to hotel companies. Retrieved 31 August 2017 from website: http://www.elevenmyanmar.com/business/two$\underline{\text { islands-taninthayi-region-rented-hotel-companies }}$

Ellis, S. and L. Sheridan (2014) A critical reflection on the role of stakeholders in sustainable tourism development in Least-Developed Countries. Tourism Planning and Development, 11: 467-471.

Fennell, D. (2015) Ecotourism (Fourth edition). London: Routledge.

Fletcher, R. (2011) Sustaining tourism, sustaining capitalism? The tourism industry's role in global capitalist expansion. Tourism Geographies 13: 443-461.

Financial Times (2017) Myanmar's foreign direct investment rush recedes. 23 January. Retrieved 31 August 2017 from website: https://www.ft.com/ 
Findlay, R., Park, C.-Y. and J-P. A. Verbiest (2016) Myanmar: building economic foundations. Asian Pacific Economic Literature 30(1): 42-64.

Ford, M., Gillan. M and H.H. Thein (2016) From Cronyism to Oligarchy? Privatisation and Business Elites in Myanmar. Journal of Contemporary Asia, 46(1): 18-41.

Gibson, C. (2009) Geographies of tourism: critical research on capitalism and local livelihoods. Progress in Human Geography 33(4): 527-534.

Globserver (2014) The government doesn't allow homestay tourism in Myanmar. 17 February. Retrieved 31 August 2017 from website: http://globserver.cn/en/asia/press/governmentdoesn $\% \mathrm{E} 2 \% 80 \% 99 \mathrm{t}$-allow-homestay-tourism-myanmar

Hampton, M.P. (2013) Backpacker tourism and economic development. London: Routledge. Hampton, M.P. and J. Jeyacheya, (2015) Power, Ownership and Tourism in Small Islands: evidence from Indonesia. World Development. 70: 481-495.

Harvey, D. (1989) The condition of postmodernity. Cambridge, MA: Blackwell

Henderson, J. C. (2003). The politics of tourism in Myanmar. Current Issues in Tourism, 6: $97-118$.

Holden, A. (2013) Tourism, poverty and development. London: Routledge.

Hudson. S. (2016) Let the journey begin (again): The branding of Myanmar. Journal of Destination Marketing \& Management, 5: 305-313.

Human Rights Watch (2010) State control and civil society in Burma after Cyclone Nargis. Retrieved 31 August 2017 from website: http://www.hrw.org

Igoe, J., Neves, K., and D. Brockington (2010) A spectacular eco-tour around the historic bloc: theorising the convergence of biodiversity conservation and capitalist expansion.' Antipode, 43(3): 486-512.

Jones, L. (2014) The political economy of Myanmar's transition. Journal of Contemporary Asia, 44(1): 144-170. 
Klein, N. (2007) The shock doctrine: the rise of disaster capitalism. Toronto: Random House. Lee, D., Hampton, M., and J. Jeyacheya (2015) The political economy of precarious work in the tourist industry in Small Island Developing States. Review of International Political Economy. 22 (1): 194-223.

Lwin, E.E.T. and H. Thant, (2016) NLD reduces government ministries. Myanmar Times, 18 March. Retrieved 24 August 2017 from website: http://www.mmtimes.com/nationalnews/nay-pyi-taw/19532-nld-reduces-government-ministries.html

McPherson, P. (2017a) Aung San Suu Kyi: Myanmar's great hope fails to live up to expectations. The Guardian. 31 March. Retrieved 31 August 2017 from website: https://www.theguardian.com/world/2017/mar/31/aung-san-suu-kyi-myanmars-great-hopefails-to-live-up-to-expectations

McPherson, P. (2017b) Dozens killed in fighting between Myanmar army and Rohingya militants. The Guardian. 25 August. Retrieved 31 August 2017 from website: https://www.theguardian.com/world/2017/aug/25/rohingya-militants-blamed-as-attack-onmyanmar-border-kills-12

Ministry of Environmental Conservation and Forestry. (2011) National biodiversity strategy and action plan. Retrieved 31 August 2017 from website: http://www.cbd.int/doc/world/mm/mm-nbsap-01-en.pdf

MOECAF [Ministry of Environmental Conservation and Forestry] and MoHT [Ministry of Hotels and Tourism] 92015) Myanmar ecotourism policy and management strategy 20152025. Retrieved 31 August 2017 from website: $\underline{\text { http://portal.gms- }}$ eoc.org/uploads/resources/670/attachment/Myanmar\%20Ecotourism\%20Policy $\% 20$ and $\% 20$ Management $\% 20$ Strategy.pdf Ministry of Hotels and Tourism [MoHT] (2012a) Myanmar tourism statistics. Retrieved 31 August 2017 from website: http://www.myanmartourism.org/tourismstatistics.htm 
Ministry of Hotels and Tourism [MoHT] (2012b) Responsible tourism policy. Retrieved 31 August 2017 from website: http://www.burmalibrary.org/docs14/Myanmar_ResponsibleTourism Policy-en-red-ocr-tu.pdf

Ministry of Hotels and Tourism [MoHT] (2013a) Myanmar tourism master plan 2013-2020. Retrieved 31 August 2017 from website: institute.org/Myanmar\%20Tourism\%20Master\%20Plan\%202013-2020.pdf

Ministry of Hotels and Tourism [MoHT] (2013b) Policy on community involvement in tourism (CIT). $\quad$ Retrieved 31 August 2017 from website: http://myanmartourism.org/journals/Community $\% 20$ Involvement $\% 20$ Tourism $\% 20 \mathrm{in} \% 20 \mathrm{My}$ anmar.pdf

Ministry of Hotels and Tourism [MoHT] (2015) Myanmar tourism statistics. Retrieved 31 August 2017 from website: http://www.myanmartourism.org/tourismstatistics.htm MNPED [Ministry of National Planning and Economic Development] (2013) Millennium development goals report. Retrieved 31 August 2017 from website: http://www.se.undp.org/content/dam/sweden/Rapporter/MDG\%20report\%20Myanmar.pdf Mowforth, M. and I. Munt (2016) (Fourth edition) Tourism and sustainability: Development, globalisation and new tourism in the third world. London: Routledge.

Munt, I. (1994) The 'other' postmodern tourism: culture, travel and the new middle classes. Theory, Culture and Society 11(3): 101-123.

Myanmar Centre for Responsible Business [MCRB] (2015) Myanmar tourism sector wide impact assessment. Yangon: MCRB.

Myanmar Marketing and Research Development [MMRD] (2012) Myanmar hotel and tourism review. Retrieved 31 August 2017 from website: http://www.centroestero.org/formazione/repository/19 11_2013 $10 \quad 25$ focusmyanmarmyan mar-tourism-review-12-13.pdf 
Myanmar Responsible Tourism Institute [MRTI] (2017) About us. Retrieved 31 August 2017 from website: http://www.myanmarresponsibletourism.org/

Neves, K. (2010) Cashing in on cetourism: a critical ecological engagement with dominant ENGO discourses on whaling, cetacean conservation and whale watching. Antipode 42(3): 719741

Oikos (2015) Lampi Marine National Park ecotourism plan 2015-2018. Retrieved 31 August 2017 from website: www.istituto-oikos.org

Organisation for Economic Cooperation and Development [OECD] (2014) OECD Investment policy reviews: Myanmar. Paris: OECD.

Parnwell, M. J. G. (2002) Tourism, globalisation and critical security in Myanmar and Thailand. Singapore Journal of Tropical Geography 19: 212-231.

Prasse-Freeman, E. (2012) Power, civil society and an inchoate politics of the daily in Burma/Myanmar. Journal of Asian Studies 71(2): 371-397

Rammohan, A., and B. Pritchard (2014) The role of landholding as a determinant of food and nutrition insecurity in rural Myanmar. World Development 64: 597-608.

Sanford, D.M. and H. Dong (2000) Investment in familiar territory: tourism and new foreign direct investment. Tourism Economics 6(3): 205-219.

Saw, Y.M., Win, K.L., Shiao, L.W.-S., Thandar, M.M., Amiya, R.M., Shibanuma, A., Tun, S., and M. Jimba (2013) Taking stock of Myanmar's progress toward the health-related Millennium Development Goals: current roadblocks, paths ahead. International Journal for Equity in Health 12: 78.

Scheyvens, R. (2011a) Tourism and poverty. London: Routledge.

Scheyvens, R. (2011b) The challenge of sustainable tourism development in the Maldives: Understanding the social and political dimensions of sustainability. Asia Pacific Viewpoint, 52(2): 148-164. 
Shen, S. (2017) Why crony capitalism continues to thrive in Myanmar. (Translated by A. Lee). ejinsight. Online. 24 March. Retrieved 24 August 2017 from website: http://www.ejinsight.com/20170324-why-crony-capitalism-continues-to-thrive-in-myanmar/ Simpson, A. and S. Park (2013) The Asian Development Bank as a global risk regulator in Myanmar. Third World Quarterly 34(10): 1858-1871.

Thett, K. K. (2012) Responsible tourism in Myanmar: Current situation and challenges. Prague: Burma Centre.

Thu, E.E. and T. Kean (2015) Why Myanmar's tourist numbers don't add up. Myanmar Times, 19 January. Retrieved 31 August 2017 from website: http://www.mmtimes.com/index.php/indepth/12828-why-myanmar-s-tourist-numbers-don-t-add-up.html

United Nations World Tourism Organisation [UNWTO] (2015) Tourism and the sustainable development goals. Madrid: UNWTO. Retrieved 31 August 2017 from website: http://www.eunwto.org/doi/pdf/10.18111/9789284417254

Valentin, A. and D. Schilcher (2017) Visiting oppressive states: Tourism in Laos, Cambodia and Myanmar. In The Routledge Handbook of Tourism in Asia. Hall, C.M. and S. Page (eds). London: Routledge.

World Travel and Tourism Council [WTTC] (2016) Travel \& Tourism: Economic Impact 2016 Myanmar. Retrieved 31 August 2017 from website: http://www.wttc.org/research/economicimpact-research/country-reports/m/myanmar/

Zhang, J. and C. Jensen (2007) Comparative advantage: explaining tourism flows. Annals of Tourism Research 34(1): 223-243.

Zhou, P. (2005) Troubling travels: funding Myanmar's junta. Harvard International Review 26: 9-10. 
Figure 1 Recorded (MOHT, 2015) and projected (MMRD, 2012) international visitor arrivals to Myanmar

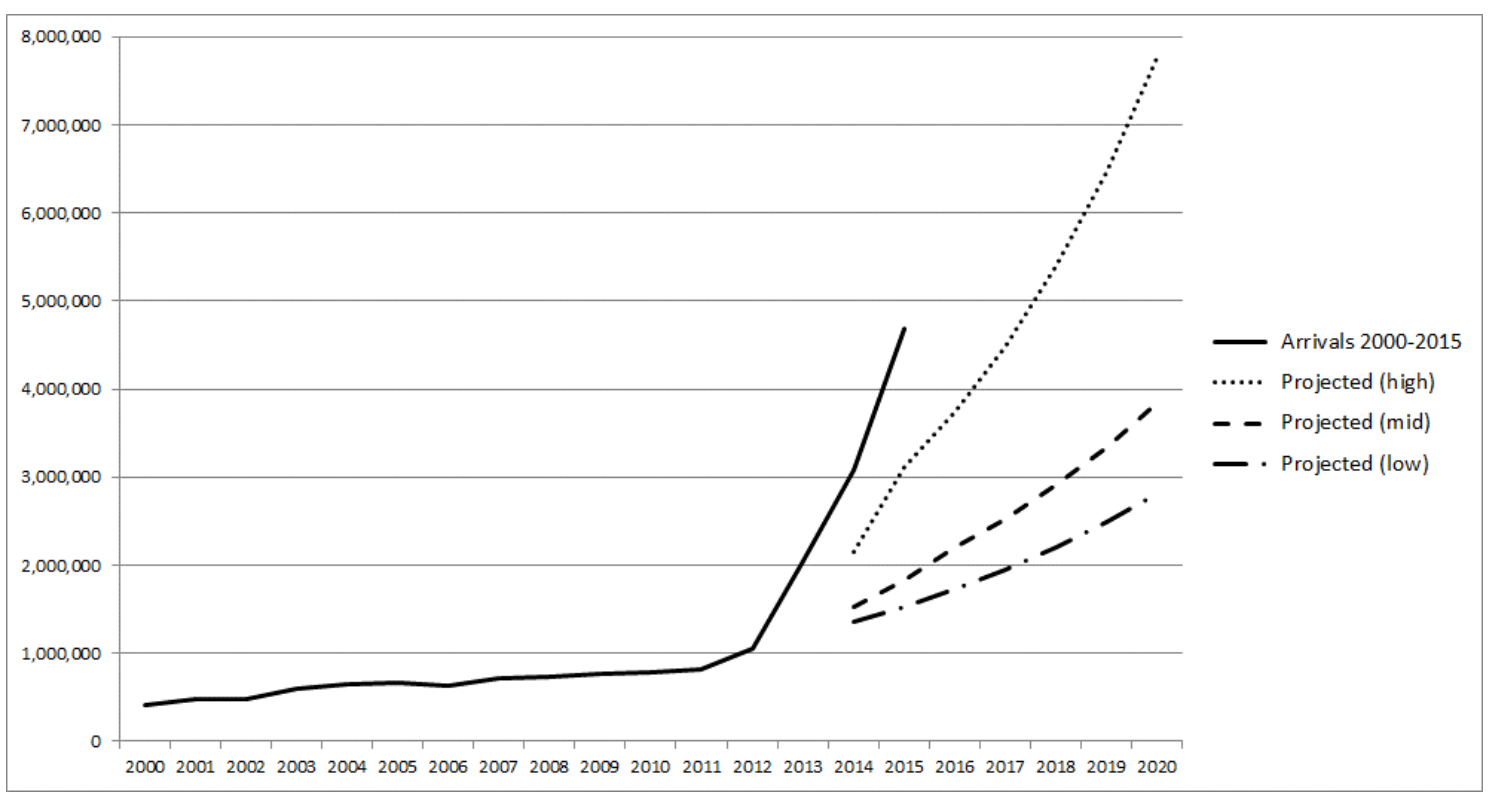


Figure 2

\section{Responsible Tourism Policy: Guiding principles}

Develop wousen as a notional prioricy sector

Maintain culourd diversity and auflenticky

Coepese on peoduct ticliness, diversicy and qualioy

Sortighthen instuxioeal caposity to plan and samage tourise:

Mininise methical prectioes
Pronote beoad besstheal socio-ecoecend develognent

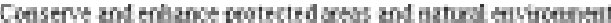

Ensone visioors' heabh, safecy and socuricy.

Prowste a well trined andecxardst wodforce

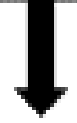

Tourism Master Plan: Strategic programmes
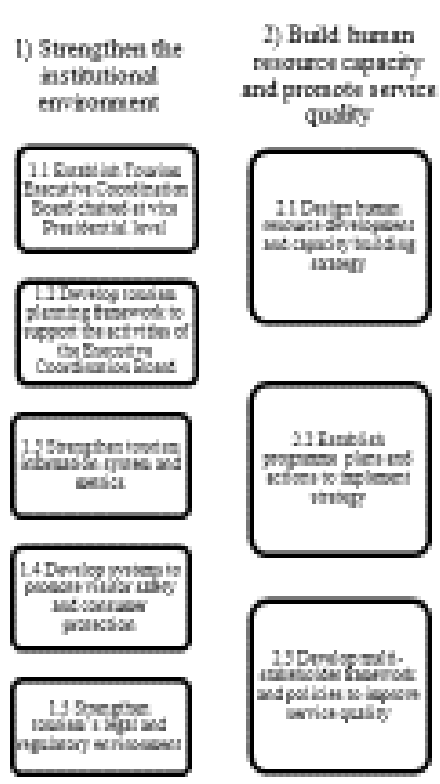

3) Sontighen

saft guards and

peocedures foe

denamaben plarning

and nansagement

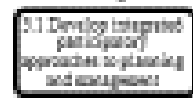

Pronserions

wate

\section{3leners asiag is}

i4Dinespidiperios

invein for iostis

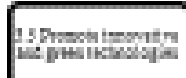

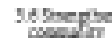

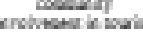

4) Develey gualty peoducts and strioes

5) Irprove

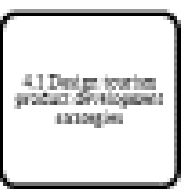

$4204 x-24$

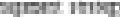

for mincind ron

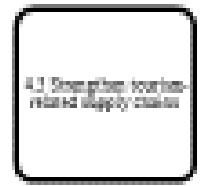

ectunectuvity and

baurimbalated

infrasoucture
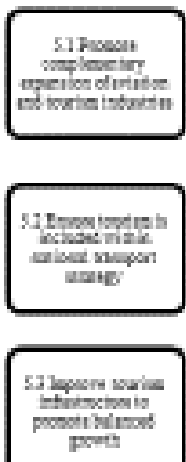

6) Buld the inage, monsibet and brand of Tounisn Myonese

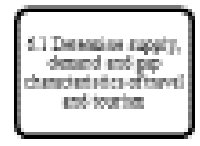

oflarnsong:

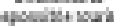

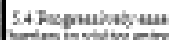

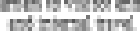

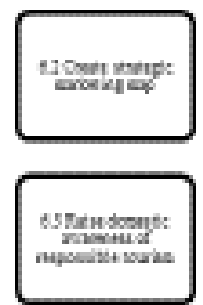

24 Yonp

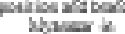

innwiod ut 
Figure 3 Foreign direct investment data by sector 2004-2011 and 2012-2016 (DCIM, 2016)

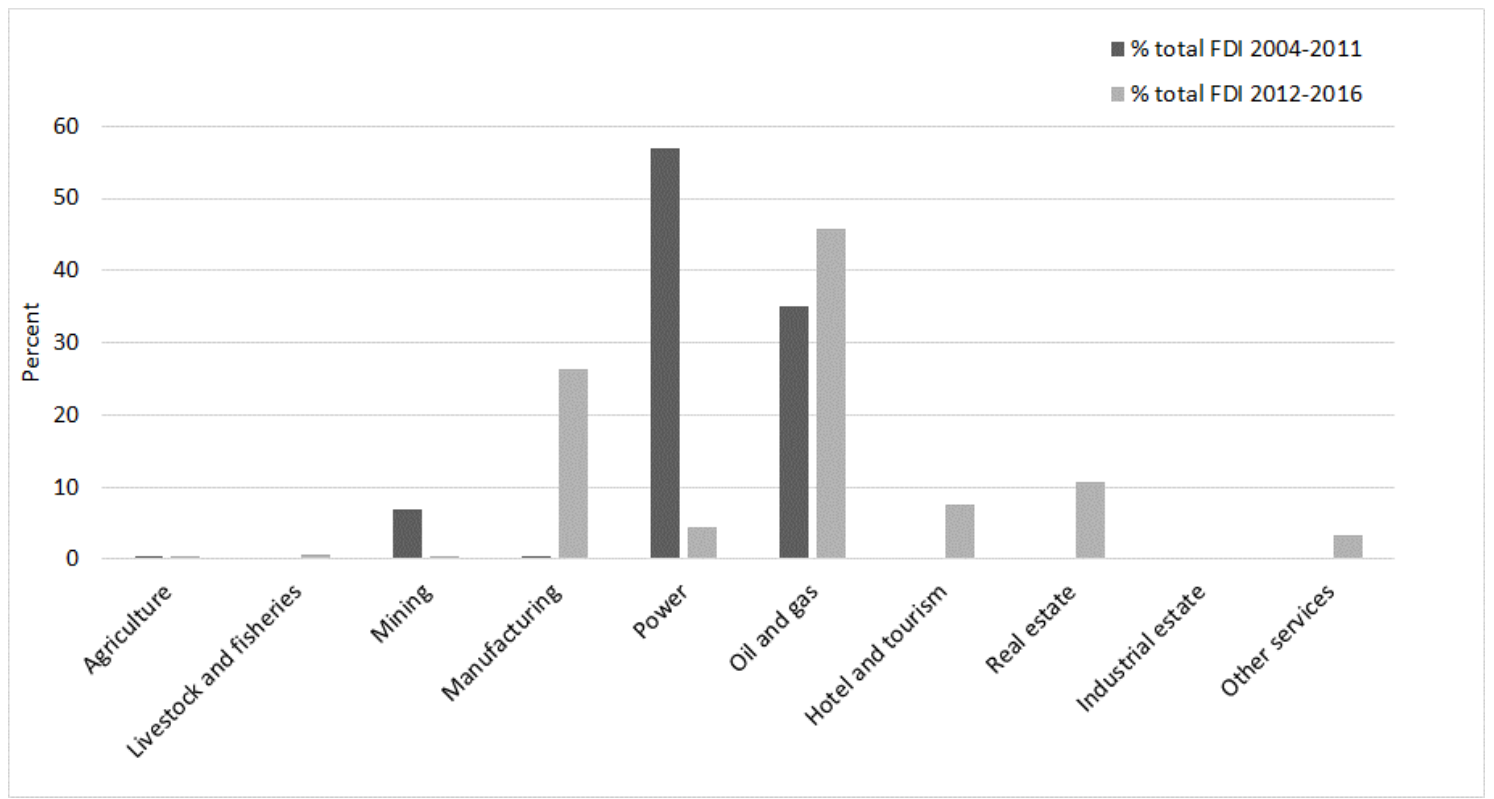


Table 1. Tourism data for Myanmar 2000-2015

\begin{tabular}{|c|c|c|c|c|c|c|c|c|c|c|c|c|c|c|c|c|}
\hline & $\begin{array}{c}200 \\
0\end{array}$ & $\begin{array}{c}200 \\
1\end{array}$ & $\begin{array}{c}200 \\
2\end{array}$ & $\begin{array}{c}200 \\
3\end{array}$ & $\begin{array}{c}200 \\
4\end{array}$ & $\begin{array}{c}200 \\
5\end{array}$ & $\begin{array}{c}200 \\
6\end{array}$ & $\begin{array}{c}200 \\
7\end{array}$ & $\begin{array}{c}200 \\
8\end{array}$ & $\begin{array}{c}200 \\
9\end{array}$ & $\begin{array}{c}201 \\
0\end{array}$ & $\begin{array}{c}201 \\
1\end{array}$ & 2012 & 2013 & 2014 & 2015 \\
\hline \multicolumn{17}{|c|}{ International arrivals ${ }^{\text {a }}$} \\
\hline & $\begin{array}{l}416, \\
344\end{array}$ & $\begin{array}{l}475 \\
106\end{array}$ & $\begin{array}{l}487, \\
490\end{array}$ & $\begin{array}{l}597, \\
015\end{array}$ & $\begin{array}{l}656, \\
910\end{array}$ & $\begin{array}{l}660, \\
206\end{array}$ & $\begin{array}{l}630 \\
061\end{array}$ & $\begin{array}{l}716, \\
434\end{array}$ & $\begin{array}{l}731, \\
230\end{array}$ & $\begin{array}{l}762, \\
547\end{array}$ & $\begin{array}{l}791, \\
505\end{array}$ & $\begin{array}{l}816, \\
369\end{array}$ & $\begin{array}{c}1,058 \\
\text {,995 }\end{array}$ & $\begin{array}{c}2,044 \\
, 307\end{array}$ & $\begin{array}{c}3,081 \\
, 412\end{array}$ & $\begin{array}{l}4,681 \\
, 020\end{array}$ \\
\hline \multicolumn{17}{|c|}{ Point of entry ${ }^{a}$} \\
\hline $\begin{array}{l}\text { Bord } \\
\text { er }^{1}\end{array}$ & $\begin{array}{l}208, \\
679\end{array}$ & $\begin{array}{l}270 \\
244\end{array}$ & $\begin{array}{l}270 \\
278\end{array}$ & $\begin{array}{l}391, \\
405\end{array}$ & $\begin{array}{l}414, \\
972\end{array}$ & $\begin{array}{l}427, \\
988\end{array}$ & $\begin{array}{l}366, \\
547\end{array}$ & $\begin{array}{l}468, \\
358\end{array}$ & $\begin{array}{l}537, \\
911\end{array}$ & $\begin{array}{l}519 \\
269\end{array}$ & $\begin{array}{l}480, \\
817\end{array}$ & $\begin{array}{l}425, \\
193\end{array}$ & $\begin{array}{c}465,6 \\
14\end{array}$ & $\begin{array}{l}1,144 \\
, 146\end{array}$ & $\begin{array}{r}1,949 \\
, 788\end{array}$ & $\begin{array}{r}3,379 \\
, 437\end{array}$ \\
\hline $\begin{array}{l}\text { Yang } \\
\text { on }\end{array}$ & $\begin{array}{l}206, \\
778\end{array}$ & $\begin{array}{l}203, \\
200\end{array}$ & $\begin{array}{l}212, \\
468\end{array}$ & $\begin{array}{l}198 \\
435\end{array}$ & $\begin{array}{l}236, \\
370\end{array}$ & $\begin{array}{l}227, \\
300\end{array}$ & $\begin{array}{l}257, \\
594\end{array}$ & $\begin{array}{l}242, \\
535\end{array}$ & $\begin{array}{l}187, \\
766\end{array}$ & $\begin{array}{l}234, \\
417\end{array}$ & $\begin{array}{l}297 \\
246\end{array}$ & $\begin{array}{l}364, \\
743\end{array}$ & $\begin{array}{c}559,6 \\
10\end{array}$ & $\begin{array}{c}817,6 \\
99\end{array}$ & $\begin{array}{c}1,022 \\
, 081\end{array}$ & $\begin{array}{r}1,180 \\
, 682\end{array}$ \\
\hline $\begin{array}{l}\text { Man } \\
\text { dalay } \\
\& \\
\text { Baga } \\
n^{2}\end{array}$ & 887 & $\begin{array}{c}1,66 \\
2\end{array}$ & $\begin{array}{c}4,74 \\
4\end{array}$ & $\begin{array}{c}7,17 \\
5\end{array}$ & $\begin{array}{c}5,66 \\
8\end{array}$ & $\begin{array}{c}4,91 \\
8\end{array}$ & $\begin{array}{c}5,92 \\
0\end{array}$ & $\begin{array}{c}5,54 \\
1\end{array}$ & $\begin{array}{c}5,55 \\
3\end{array}$ & $\begin{array}{c}8,86 \\
1\end{array}$ & $\begin{array}{c}13,4 \\
42\end{array}$ & $\begin{array}{c}20,9 \\
12\end{array}$ & $\begin{array}{c}32,52 \\
1\end{array}$ & $\begin{array}{c}69,59 \\
6\end{array}$ & $\begin{array}{c}90,01 \\
1\end{array}$ & $\begin{array}{c}107,0 \\
66\end{array}$ \\
\hline $\begin{array}{l}\text { Nay } \\
\text { Pyi } \\
\text { Taw } \\
3\end{array}$ & - & - & - & - & - & - & - & - & - & - & - & $\begin{array}{c}5,52 \\
1\end{array}$ & 1,250 & $\begin{array}{c}11,84 \\
2\end{array}$ & $\begin{array}{c}19,26 \\
1\end{array}$ & $\begin{array}{c}13,83 \\
5\end{array}$ \\
\hline \multicolumn{17}{|c|}{ Number of scheduled inbound flights ${ }^{\text {a }}$} \\
\hline & $\mathrm{n} / \mathrm{a}$ & $\mathrm{n} / \mathrm{a}$ & $\mathrm{n} / \mathrm{a}$ & $\mathrm{n} / \mathrm{a}$ & $\mathrm{n} / \mathrm{a}$ & $\mathrm{n} / \mathrm{a}$ & $\mathrm{n} / \mathrm{a}$ & $\begin{array}{c}4,47 \\
9\end{array}$ & $\begin{array}{c}3,97 \\
9\end{array}$ & $\begin{array}{c}4,24 \\
6\end{array}$ & $\begin{array}{c}5,97 \\
4\end{array}$ & $\begin{array}{c}7,49 \\
7\end{array}$ & 8,440 & $\begin{array}{c}12,20 \\
5\end{array}$ & $\begin{array}{c}14,75 \\
9\end{array}$ & $\begin{array}{c}15,34 \\
4\end{array}$ \\
\hline \multicolumn{17}{|c|}{ Visas issued a, 4} \\
\hline Pack & & & & & & & & & & & & & & & & \\
\hline $\begin{array}{l}\text { age } \\
\text { tour }\end{array}$ & $\begin{array}{c}77,6 \\
46\end{array}$ & $\begin{array}{c}72,5 \\
03\end{array}$ & $\begin{array}{c}78,7 \\
23\end{array}$ & $\begin{array}{c}55,4 \\
69\end{array}$ & $\begin{array}{c}48,1 \\
91\end{array}$ & $\begin{array}{c}54,9 \\
89\end{array}$ & $\begin{array}{c}74,3 \\
89\end{array}$ & $\begin{array}{c}88,9 \\
41\end{array}$ & $\begin{array}{c}48,6 \\
56\end{array}$ & $\begin{array}{c}66,5 \\
52\end{array}$ & $\begin{array}{c}87,9 \\
32\end{array}$ & $\begin{array}{l}103, \\
590\end{array}$ & $\begin{array}{c}131,1 \\
15\end{array}$ & $\begin{array}{c}148,5 \\
57\end{array}$ & $\begin{array}{c}179,2 \\
83\end{array}$ & $\begin{array}{c}188,4 \\
66\end{array}$ \\
\hline FIT $^{5}$ & $\begin{array}{c}46,6 \\
90\end{array}$ & $\begin{array}{c}48,7 \\
40\end{array}$ & $\begin{array}{c}55,0 \\
17\end{array}$ & $\begin{array}{c}66,7 \\
72\end{array}$ & $\begin{array}{l}109 \\
134\end{array}$ & $\begin{array}{c}96,0 \\
75\end{array}$ & $\begin{array}{l}106 \\
140\end{array}$ & $\begin{array}{c}78,6 \\
19\end{array}$ & $\begin{array}{c}61,8 \\
84\end{array}$ & $\begin{array}{c}79,0 \\
74\end{array}$ & $\begin{array}{l}109 \\
222\end{array}$ & $\begin{array}{l}134, \\
956\end{array}$ & $\begin{array}{c}232,7 \\
15\end{array}$ & $\begin{array}{c}294,2 \\
18\end{array}$ & $\begin{array}{c}338,1 \\
99\end{array}$ & $\begin{array}{c}306,5 \\
70\end{array}$ \\
\hline $\begin{array}{l}\text { Busi } \\
\text { ness }\end{array}$ & $\begin{array}{c}37,0 \\
32\end{array}$ & $\begin{array}{c}36,6 \\
08\end{array}$ & $\begin{array}{c}37,0 \\
84\end{array}$ & $\begin{array}{c}44,1 \\
51\end{array}$ & $\begin{array}{c}40,5 \\
21\end{array}$ & $\begin{array}{c}36,1 \\
70\end{array}$ & $\begin{array}{c}35,6 \\
29\end{array}$ & $\begin{array}{c}35,4 \\
40\end{array}$ & $\begin{array}{c}36,3 \\
92\end{array}$ & $\begin{array}{c}42,5 \\
53\end{array}$ & $\begin{array}{c}48,5 \\
49\end{array}$ & $\begin{array}{c}69,9 \\
43\end{array}$ & $\begin{array}{c}114,4 \\
56\end{array}$ & $\begin{array}{c}151,3 \\
20\end{array}$ & $\begin{array}{c}186,2 \\
39\end{array}$ & $\begin{array}{c}173,0 \\
04\end{array}$ \\
\hline
\end{tabular}




\begin{tabular}{|c|c|c|c|c|c|c|c|c|c|c|c|c|c|c|c|c|}
\hline $\begin{array}{l}\text { Socia } \\
1^{6}\end{array}$ & $\begin{array}{c}8,04 \\
3\end{array}$ & $\begin{array}{c}7,75 \\
6\end{array}$ & $\begin{array}{c}9,50 \\
5\end{array}$ & $\begin{array}{c}13,1 \\
40\end{array}$ & $\begin{array}{c}16,5 \\
05\end{array}$ & $\begin{array}{c}20,5 \\
28\end{array}$ & $\begin{array}{c}22,5 \\
92\end{array}$ & $\begin{array}{c}21,3 \\
40\end{array}$ & $\begin{array}{c}21,8 \\
27\end{array}$ & $\begin{array}{c}26,2 \\
17\end{array}$ & $\begin{array}{c}28,2 \\
40\end{array}$ & $\begin{array}{c}33,2 \\
73\end{array}$ & $\begin{array}{c}37,77 \\
8\end{array}$ & $\begin{array}{c}45,56 \\
6\end{array}$ & $\begin{array}{c}45,79 \\
4\end{array}$ & $\begin{array}{c}49,44 \\
4\end{array}$ \\
\hline $\begin{array}{l}\text { Othe } \\
\text { rs }\end{array}$ & $\begin{array}{c}37,3 \\
67\end{array}$ & $\begin{array}{c}37,5 \\
93\end{array}$ & $\begin{array}{c}32,1 \\
39\end{array}$ & $\begin{array}{c}18,9 \\
03\end{array}$ & $\begin{array}{c}21,2 \\
19\end{array}$ & $\begin{array}{c}19,5 \\
38\end{array}$ & $\begin{array}{c}18,8 \\
44\end{array}$ & $\begin{array}{c}18,1 \\
95\end{array}$ & $\begin{array}{c}19,0 \\
07\end{array}$ & $\begin{array}{c}20,0 \\
21\end{array}$ & $\begin{array}{c}23,3 \\
03\end{array}$ & $\begin{array}{c}22,9 \\
81\end{array}$ & $\begin{array}{c}43,54 \\
6\end{array}$ & $\begin{array}{c}178,0 \\
38\end{array}$ & $\begin{array}{c}271,8 \\
46\end{array}$ & $\begin{array}{c}463,1 \\
98\end{array}$ \\
\hline \multicolumn{17}{|c|}{ Total number of hotel, motel and guest house rooms a } \\
\hline & $\mathrm{n} / \mathrm{a}$ & $\mathrm{n} / \mathrm{a}$ & $\mathrm{n} / \mathrm{a}$ & $\mathrm{n} / \mathrm{a}$ & $\mathrm{n} / \mathrm{a}$ & $\mathrm{n} / \mathrm{a}$ & $\mathrm{n} / \mathrm{a}$ & $\begin{array}{c}19,9 \\
61\end{array}$ & $\begin{array}{c}20,3 \\
57\end{array}$ & $\begin{array}{c}20,9 \\
42\end{array}$ & $\begin{array}{c}23,4 \\
54\end{array}$ & $\begin{array}{c}25,0 \\
02\end{array}$ & $\begin{array}{c}28,29 \\
1\end{array}$ & $\begin{array}{c}34,83 \\
4\end{array}$ & $\begin{array}{c}43,24 \\
3\end{array}$ & $\begin{array}{c}49,94 \\
6\end{array}$ \\
\hline \multicolumn{17}{|c|}{ Direct contribution to GDP (US\$ billion real prices) ${ }^{b}$} \\
\hline & 0.33 & 0.39 & 0.45 & 0.35 & 0.45 & 0.49 & 0.51 & 0.60 & 0.60 & 0.56 & 0.56 & 0.65 & 0.71 & 1.09 & 1.45 & 1.69 \\
\hline \multicolumn{17}{|c|}{ Direct contribution to employment ${ }^{b}$} \\
\hline & $\begin{array}{l}318 \\
009\end{array}$ & $\begin{array}{l}340, \\
162\end{array}$ & $\begin{array}{l}355 \\
284\end{array}$ & $\begin{array}{r}248 \\
413\end{array}$ & $\begin{array}{r}287, \\
153\end{array}$ & $\begin{array}{r}282 \\
773\end{array}$ & $\begin{array}{r}265 \\
659\end{array}$ & $\begin{array}{l}284, \\
202\end{array}$ & $\begin{array}{l}280, \\
927\end{array}$ & $\begin{array}{l}256, \\
361\end{array}$ & $\begin{array}{r}265 \\
156\end{array}$ & $\begin{array}{l}319, \\
195\end{array}$ & $\begin{array}{r}306,4 \\
85\end{array}$ & $\begin{array}{r}430,2 \\
53\end{array}$ & $\begin{array}{r}573,4 \\
64\end{array}$ & 661,0 \\
\hline
\end{tabular}

Sources: ${ }^{a}$ Ministry of Hotels and Tourism (http://www.myanmartourism.org/); ${ }^{b}$ World Travel and Tourism Council Data Gateway (http://www.wttc.org/datagateway/)

Notes

${ }^{1}$ Refers to overland entry points. Includes day visits.

${ }^{2}$ Bagan airport is also referred to as Nyaung U airport.

${ }^{3}$ Nay Pyi Taw International Airport opened in 2011.

${ }^{4}$ Data for Yangon international entry point only.

${ }^{5}$ Foreign independent travellers.

${ }^{6}$ Commonly granted to foreign nationals visiting relatives resident in Myanmar and those visiting for meditation purposes. 
Table 2: The local and international perspective on tourism development in Ngapali. Data derived from visits in 2014 and 2016.

\begin{tabular}{|c|c|}
\hline voice & The international voice \\
\hline $\begin{array}{l}\text { "When I was very young you could walk easily } \\
\text { here (pointing to the beach) you can live on the } \\
\text { shore. Now it is all sold - the land is bought. } \\
\text { We live somewhere like that (pointing to a } \\
\text { fisherman's hut). it is not our land so now we } \\
\text { live at the bank. we don't own land or pay rent. } \\
\text { The fisherman's owner lets us stay there." (local } \\
\text { waiting staff, boutique hotel) }\end{array}$ & $\begin{array}{l}\text { "Big dreams for what they want but no } \\
\text { reasonable plan to reach it. They never had the } \\
\text { experience of this. Things are happening too } \\
\text { fast for locals. My biggest concern, if the } \\
\text { direction is Pattaya / Bali this main street will } \\
\text { have bars, clubs, prostitution because they are } \\
\text { different guests, different styles. Young ladies } \\
\text { will become prostitutes - there is a good chance } \\
\text { for money" (expatriate, businessman, German) }\end{array}$ \\
\hline $\begin{array}{l}\text { "The headman is not interested in tourism } \\
\text { development at the moment, but he is buying up } \\
\text { land speculatively for future sales." (local lodge } \\
\text { owner) }\end{array}$ & $\begin{array}{l}\text { "People who lived in little wooden houses, they } \\
\text { move, build a much better place, perhaps buy a } \\
\text { taxi. get a better life" (expatriate, hotel manager, } \\
\text { British) }\end{array}$ \\
\hline $\begin{array}{l}\text { "Planning for region is not shared with us but } \\
\text { we have heard about a plan of some kind." } \\
\text { (local restaurant and shop owner) }\end{array}$ & $\begin{array}{l}\text { "There is friendly but intense competition about } \\
\text { who is going to be number } 1 \text { on trip advisor." } \\
\text { (expatriate manager of boutique hotel, Austrian) }\end{array}$ \\
\hline $\begin{array}{l}\text { "We want to be involved in tourism and } \\
\text { included in the plans. Tourists come and see } \\
\text { how poor we are. We don't want that. It makes } \\
\text { us depressed". (local fisherman) }\end{array}$ & $\begin{array}{l}\text { "It's [tourism] a good thing. the beaches are too } \\
\text { empty" (expatriate chef at } 5 * \text { resort, Australian) }\end{array}$ \\
\hline
\end{tabular}




\section{Notes.}

${ }^{1}$ The country's official name was changed from Burma to Myanmar in 1989.

${ }^{2}$ This paper uses the UNWTO definition of a tourist which includes travelling to, and staying in places away from one's usual environment for leisure, business or other purposes for less than a year consecutively. This definition also excludes day visits which for some crossborder tourism from proximate countries is problematic if all international arrivals are recorded in aggregate rather than dividing day visits from staying visitors. In many ASEAN countries this separation is not made, raising serious questions over the accuracy of headline international arrivals figures (Mowforth and Munt, 2016). Additionally, in Myanmar's case, to make life easier and avoid bureaucracy (and cost), some business and other visitors simply list themselves as 'tourist' on their arrival card (in fairness this also happens in several neighbouring countries as well) but again, this points to the need to examine official international arrivals figures carefully. Valentin and Schilcher (2017: 214) go further noting that the 'suspicion is that the Myanmar government exaggerates the increase in tourists in an effort to enhance the image of the country as a tourist destination and to attract more investors' (emphasis added).

${ }^{3}$ During 2017 Flora \& Fauna International produced a map of 'at risk' marine environments in southern Myanmar including around Lampi Marine Park (http://www.faunaflora.org/explore/myanmar/ ). It is possible that the new mapping of fragile eco-systems including both coral and mangroves may lead to some reviewing by government of plans to allow further tourist resort development in this area. 